\title{
Additive Effect of Chitinase Genes in Transconjugants of Entomopathogens Bacillus thuringiensis to Improve Biological Control of Tuta absoluta Heba H. Atia ${ }^{2}$; Mervat I. Kamal ${ }^{1}$; A. I. El Sayed ${ }^{2}$;. M. El- Adl ${ }^{1}$ and K. A. Zaied ${ }^{1}$ ${ }^{1}$ Department of Genetics, Faculty of Agriculture, Mansoura University. \\ ${ }^{2}$ Water, Soil and Environmental Research Institute, Agriculture Research Center, Giza, Egypt.
}

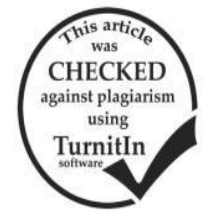

\section{ABSTRACT}

This study aimed to evaluate the toxicity of Bacillus thuringiensis $(B t)$ transconjugants harboring chitinase genes against larval stage of Tuta absoluta. Bacillus licheniformis and Serratia marcescens were used as donors against Bt . Bacillus transconjugants were evaluated for chitinase activity depending on hydrolysis zone appeared on chitin agar medium. Parental strains and their recombinants significantly reduced the number of survived larvae if compared with untreated larvae. Mortality rate was gradually increased to reached a maximum ratio after six days of treatments. Most bioinsecticides including parental strains and their transconjugants significantly losses larval body weight daily if compared with untreated larvae. Bioinsecticides, as well as, bioinsecticide concentrations and the interaction between both factors showed negative significant effect on larval body weight at most time intervals of larval age. In addition, $B t$ recombinants , as well as, their parental strains has exhibited a great potential effect for controlling and suppress the feeding of larval stage on the host plants.

Keywords: Bacillus thuringiensis, conjugation, larval mortality, larval weight, Tuta absoluta .

\section{INTRODUCTION}

Tuta absoluta was one of the important pests which is threating to tomato production in Egypt (Sabbour 2014). Infection by T. absoluta had resulted in $60-100 \%$ losses in tomato (Cely et al. 2006). Larvae can attack tomato plants during all growth stages, producing high galleries in leaves, burrowing stalks, apical buds, green and ripe fruits (IAN 1994), causing losses of tomato production (Caceres 1992). The larval stage feed on mesophyell tissues and make irregular mine on leaf surface. Damage can reached up to $100 \%$. This pest damage occurs throughout the entire growing cycle of tomatoes. Bacillus thuringiensis, an entomopathogenic bacterium, has also been used in the biocontrol of tomato insect pests (Marques and Alves 1996).

Chitinase enzyme induced damage to the peritrophic membrane in the pest gut causes a significant losses in nutrient metabolism and consequently reduced insect growth (Terra and Ferreira 2005). Chitinolytic bacteria have been shown to be important agents for biocontrol of both pathogenic fungi and insect pests (Sampson and Gooday 1998). One of the almost important insecticidal microbes used in bio-control is Bacillus thuringiensis $(B t)$, that developed delta endotoxin protein(s) during the stationary phase of the growth. $B$. thuringiensis var. kurstaki (Btk) caused mortality in all $T$. absoluta instars and the use of $B t$ has synergistic effects when applied to tomato resistant genotypes (Giustolin et al. 2001). Serratia marcescens was one of the almost higher chitin-degraders and many types of chitinase producer genes have been decided in many strains of serratia, such as ChiA, ChiB, and ChiCl (Suzuki et al. 2002).

Over-expression of chitinase in entomopathogenic microbes could increase insect mortality (Fan et al. 2007). Recently, a number of heterologous Chi genes had been transfered from different bacterial strains into B. thuringiensis to increase their insecticidal activity against insects. (Bhattacharya et al. 2007). In this area, Ozgen et al. ( 2013 ) introduced $c h i B$ and $c h i C$ genes from $S$. marcescens into some $B$. thuringiensis strains which leading to increased insecticidal activity. Similar works were done by many researchers and they all reported to improved insecticidal activity by the improved strains (Driss et al. 2011).

Transfer of bacterial plasmids via conjugation was the most efficient method of horizontal gene spread, therefore, considered one of the important reasons for increasing the number of bacteria that exhibited multipleantibiotic resistance (Grohmann et al. 2003). Plasmid transfer between $B$. thuringiensis strains could be monitored directly by the plasmid profiling analysis of cells. This is possible when transfer frequencies are high and all recipients in a population become transconjugants (Aronson and Beckman 1987).

Thus, this study aimed to induce genetic recombinants in some strains of Bacillus thuringiensis via conjugal transfer of plasmids from the donars to the reciepients to increase their insecticidal activity against tomato pest, Tuta absoluta.

\section{MATERIALS AND METHODS}

\section{Bacterial strains and their culture conditions}

Bacterial strains used in this study are listed in Table 1.

\section{Bacterial culture conditions}

Luria broth medium (LB broth) was used for Bacillus thuringiensis and Bacillus licheniforms according to Sambrook et al. (1989). Peptone yeast extract medium (PWYE) was used for separation of crystals and endospores according to Karamanlidou et al. (1991). Peptone glycerol medium (PGM) was used to enhance pigmentation, as well as, for the maintenance of Serratia marcescens according to Harris et al. (2004). However, mineral medium (MM) named M9 minimal medium was used as a minimal medium in mating experiments according to Sambrook et al. (1989). In addition, sporulation medium (MSM) was used for sporulation as previously described by Ellar and Postage (1974), with the exception of some modifications according to Gordon et al. ( 1981 ) .

\section{Colloidal chitin medium}

Colloidal chitin was prepared from chitin flakes aacording to Mathivanan et al. (1997). The medium was prepared according to Agrawal and Kotasthane (2012). 
Table 1. Bacterial strains and their sources .

\begin{tabular}{lcc}
\hline Strains & Source or reference & Designation \\
\hline $\begin{array}{l}\text { Serratia marcescens } \\
\text { Bacillus licheniforms }\end{array}$ & $\begin{array}{c}\text { Microbial Activity Unit, Microbiology Dept., Soil, Water and Environmental } \\
\text { Research Institute, Agricultural Research Center (ARC). }\end{array}$ & $S m$ \\
\hline $\begin{array}{l}\text { Bacillus thuringiensis 4A7 } \\
\text { Bacillus thuringiensis 4Q1 }\end{array}$ & $\begin{array}{c}\text { National Center for Agriculture Utilization Research, USA. } \\
\text { Daniel R. Zeigler, Ph.D., Bacillus Genetic Stock Center, Biochemistry Dept., Ohio } \\
\text { University, Columbus, USA. }\end{array}$ & $B L$ \\
\hline $\begin{array}{c}\text { Daniel R. Zeigler, Ph.D. Bacillus Genetics Stock Center, Biochemistry Dept., Ohio } \\
\text { University, Columbus, USA. }\end{array}$ & $\mathrm{Bt}_{t_{2}}$ \\
\hline
\end{tabular}

\section{Antibiotics used}

Auxotrophic and antibiotic genetic markers are an important selectable tools in the development of bacterial recombinants. Ideally, the antibiotic markers allow efficient selection for bacterial recombinants without affecting any of cellular metabolism. Antibiotic resistance or sensitive genetic markers are alternative to auxotrophic mutant markers. Thus, fourteen antibiotics were used in this investigation with different concentrations $(\mu \mathrm{g} / \mathrm{ml})$ as shown in Table 2.

Table 2. Antibiotics and their concentrations used in this study against bacterial strains.

\begin{tabular}{lcc}
\hline Antibiotics & Abbreviations & $\begin{array}{c}\text { Concentration } \\
(\mu \mathbf{g} / \mathbf{m l})\end{array}$ \\
\hline Chloramphenicol & $\mathrm{Cm}$ & 35 \\
Ampicillin & $\mathrm{Ap}$ & 50 \\
Tetracycline & $\mathrm{Tc}$ & 20 \\
Penicillin & $P c$ & 150 \\
Neomycin sulphate & $\mathrm{Nm}$ & 800 \\
Erythromycin-ethlsuccinate & Eryth & 20 \\
Rifampicin & $R i f$ & 150 \\
Vancomycin & $V c$ & 150 \\
Hibiotic & $\mathrm{Hb}$ & 400 \\
Amoxycillin & $\mathrm{Am}$ & 400 \\
Ceftazidime & $\mathrm{Ce}$ & 400 \\
Cefotaxime & $\mathrm{Cf}$ & 400 \\
Cefoperazone & $\mathrm{Cp}$ & 150 \\
Genamycin & $\mathrm{Gm}$ & 20 \\
\hline
\end{tabular}

\section{Target insect}

A wild type strain of Tuta absoluta was used in this study. It was collected from the Plant Mangment

Farmer, Sakha Research Station, Agriculture Research Center, Kafr El-Sheikh Governorate - in June, 2015. This strain was collected as a colony of eggs on untreated tomato leaves without any insecticides treatment . Egg colony were kept in Petri-dishes covered with cotton cloth. The Petri-dishes were daily supplemented with tomato leaves as a source of food till hatching. Newly hatched larvae at six days old were transfered to feeding on tomato leaves treated with $B t$ bioinsecticides via a dipping method, although leaves dipped in water were used as a control. Larvae of Tuta absoluta were put in glass jar $(250 \mathrm{ml})$ and feeding on treated tomato leaves added daily.The leaves used in this experiment were cut from the first to the ninth node of the plant from the stem. Insects were reared on tomato leaves in a laboratory under constant conditions of $25 \pm 2^{\circ} \mathrm{C}$, and $16: 8$ light : dark photoperiod regime and relative humidity $75 \pm 5 \%$ ( El- Adl et al. 2016) .

\section{Genetic marking}

Antibiotic susceptibility test was used in this investigation for genetic marking bacterial strains. Susceptibility to antibiotics was assayed by the plate diffusion technique according to Collins and lyne (1985).

\section{Conjugation procedure}

Mating experiments were performed using Serratia marcescens and Bacillus Licheniforms as a donor strains, agains Bacillus thuringiensis as a recipient. Transconjugant single colonies appeared on selective medium were picked up and transfered to LB slant agar medium according to Grinsted and Bennett (1990).

Screening chitinolytic activity

For evaluating of chitinase - producing microorganisms, a mineral medium containing colloidal chitin was used according to Someya et al. (2011).

Separation of crystals and endospores

Bacteria were grown in petri dishes to be collected the pellets of spores and crystals from nutrient agar plates which washed two times in ice-cold distilled water. Then resuspended the pellets in small volumes of distilled water. Spores and crystals were collected by centrifugation and final pellets were resuspended in $20 \mathrm{ml}$ of water and maintained in a refrigerator freezer according to Karamanlidou et al. (1991).

\section{Bioassays of bioinsecticide toxicity}

To assess the activity of bioinsecticides dipping technique was applied as described by Tabashnik et al. (1991), where fresh tomato leaves were immersed in each of the tested concentration for $30 \mathrm{sec}$. Eight bioinsecticides in addition to the control were used with three replicates for each concentration. The effects of bioinsecticides was evaluated against six days - old larvae of Tuta absoluta (mean weight $=0.0039 \mathrm{mg}$ ) at $25^{\circ} \mathrm{C}$ under laboratory conditions.

Three grams of $B t$ treated leaves were added daily to a new breeding bottle. The survived larvae were counted daily, weighting and then moved to clean jars supplemented with treated leaves except the control which supplemented with untreated leaves until pupation. The leaves were replaced daily by another treated ones after the jars were cleaned and dryed. Larval lethality was measured daily up to pupation developed. Lethality percentage was corrected by abbott formula (Abbott 1925) as follows:

\section{Abbott's formula}

\footnotetext{
Control survival-Treatment survival

$\%$ Mortality $=\frac{\text { Control survival }- \text { Treatment survival }}{\text { Control survival }} \times 100$

Toxicity index (Sun 1950) was calculated using the following formula:

Toxicity index $($ TI $)=$

$\mathrm{LC}_{50}$ of the efficient bioinsecticide / $\mathrm{LC}_{50}$ of the other

bioinsecticide $\times 100$.
} 
The feeding deterrent index (FDI) for each treatment was calculated as $(C-T) /(C+T) \times 100$.

Where $\mathrm{C}$ and $\mathrm{T}$ are the control and treated leaf areas consumed by the larva, respectively (Isman et al. 1990).

\section{Statistical analysis:}

Data were subjected to the statistical analysis of variance according to Snedecor and Cochran (1955). Least significant difference (L.S.D.) was used to compare between means if the F-test was significant .

\section{RESULTS AND DISCUSSION}

Genetic markers related to antibiotic resistance

The results presented in Table 3 illustrated the resistance / sensitive pattern of 14 antibiotics tested by disc diffusion technique on nutrient agar plates against four bacterial strains. The pattern of these strains showed multipled resistance and sensitive against the antibiotics . The results showed that Serratia marcescens was resistant to penicillin and erythromycin-ethlsuccinate , whereas sensitive to other antibiotics. However, Bacillus licheniforms was resistant to ampicillin, cefoperazone, hibiotic, amoxycillin, ceftazidime cefotaxime, and sensitive to other antibiotics .In addition, $B t_{1}$ showed resistant to ampicillin, penicillin, hibiotic, amoxycillin, ceftazidime, gentamycin and sensitive to other antibiotics. However, $B t_{2}$ was resistant to penicillin, ceftazidime, genamycin, whereas sensitive to other antibiotics . All bacterial strains tested were resistant to penicillin, whereas sensitive to chloramphenicol, tetracycline, neomycin sulphate, rifampicin, vancomycin and cefoperazone. These results are in agreement with Bautista and Teves (2013), who found that $B t$ strains were resistant to $\beta$ - lactams (amoxicillin and ampicillin). Bernhard et al. (1987) found that Bacillus strains isolated from the soil were resistant to four different antibiotics .

Conjugation between bacterial strains

In this study, plasmid transfer via conjugation was carried out between Serratia marcescens , Bacillus licheniforms as a donor strains against different strains of Bacillus thuringiensis as a recipients depending on the oppsite genetic markers harboring strains ( Table 4). Transconjugants appeared on selective medium were picked up and maintained on nutrient agar slants. Horizontal transfer mechanism of DNA between bacterial species may played a significant role in evolutionary bacteria. Gene transfer may occurred between distantly related bacterial species. Bacterial conjugation is one of gene transfer mechanism ( Mazodier and Davies 1991). Plasmids were transfered in a wide range of bacterial species between distantly related bacteria (Farrand 1993). Conjugative transfer of bacterial plasmids is the most imortant tool of horizontal gene spread and it is, therefore, considered one of the major reasons for increasing the number of bacteria that exhibited multiple-antibiotic resistance (Grohmann et al. 2003).

Table 3. Genetic markers of different bacterial strains depending on resistance (+) and sensitive ( - ) to antibiotics.

\begin{tabular}{lcccc}
\hline \multirow{2}{*}{ Antibiotics } & \multicolumn{4}{c}{ Strains } \\
\cline { 2 - 5 }$C m$ & Sm & $\boldsymbol{B L}$ & $\boldsymbol{B t}_{\boldsymbol{I}}$ & $\boldsymbol{B t}_{\mathbf{2}}$ \\
\hline$A p$ & - & - & - & - \\
$T c$ & - & + & + & - \\
$P c$ & - & - & - & - \\
$N m$ & + & + & + & + \\
$E r y t h$ & - & - & - & - \\
$R i f$ & + & - & - & - \\
$V c$ & - & - & - & - \\
$H b$ & - & - & - & - \\
$A m$ & - & + & + & - \\
$C e$ & - & + & + & - \\
$C f$ & - & + & + & + \\
$C p$ & - & + & - & - \\
$G m$ & - & - & - & - \\
& - & - & + & + \\
\hline
\end{tabular}

Table 4. Conjugation between Serratia, B. lichenformis as a donor strains against Bacillus thurinogiensis as a recipient strains.

\begin{tabular}{|c|c|c|c|c|c|c|}
\hline Mating & $\begin{array}{c}\text { Parental } \\
\text { genotypes }\end{array}$ & $\begin{array}{c}\text { Suitable time } \\
\text { needed for genetic } \\
\text { transfer }\end{array}$ & $\begin{array}{c}\text { Time needed to appeared } \\
\text { transconjugants on selective } \\
\text { media (day) }\end{array}$ & $\begin{array}{c}\text { Recombinant } \\
\text { genotype }\end{array}$ & Transconjugants & $\begin{array}{l}\text { Renamed of } \\
\text { Transconjugants } \\
\text { used in this study }\end{array}$ \\
\hline$S m X B t_{l}$ & $\begin{array}{l}\text { Ap } \text { Eryth }^{+} \\
X \\
\text { Ap }^{+} \text {Eryth }^{-}\end{array}$ & 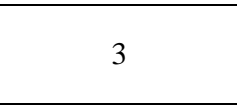 & (2) & $\mathrm{Ap}^{+}$Eryth $^{+}$ & $\begin{array}{l}\operatorname{Tr}_{2} \\
\operatorname{Tr}_{6}\end{array}$ & $\begin{array}{l}\operatorname{Tr}_{1} \\
\operatorname{Tr}_{2}\end{array}$ \\
\hline $\mathrm{Sm} X \mathrm{Bt}_{2}$ & $\begin{array}{l}C e^{-} \text {Eryth }^{+} \\
\quad X \\
\mathrm{Ce}^{+} \text {Eryth }^{-}\end{array}$ & 6 & 4 & $\mathrm{Ce}^{+}$Eryth $^{+}$ & $\begin{array}{l}\operatorname{Tr}_{14} \\
\operatorname{Tr}_{20}\end{array}$ & $\begin{array}{l}\operatorname{Tr}_{3} \\
\operatorname{Tr}_{4}\end{array}$ \\
\hline$B L X B t_{l}$ & $\begin{array}{c}C f^{+} G m^{-} \\
\quad X \\
C f^{-} G m^{+}\end{array}$ & 10 & 3 & $C f^{+} \mathrm{Gm}^{+}$ & $\begin{array}{l}\operatorname{Tr}_{22} \\
\operatorname{Tr}_{27}\end{array}$ & $\begin{array}{l}\operatorname{Tr}_{5} \\
\operatorname{Tr}_{6}\end{array}$ \\
\hline$B L X B t_{2}$ & $\begin{array}{c}C f^{+} G m^{-} \\
X \\
C f^{-} \mathrm{Gm}^{+}\end{array}$ & 3 & 3 & $C f^{+} \mathrm{Gm}^{+}$ & $\begin{array}{l}\operatorname{Tr}_{33} \\
\operatorname{Tr}_{39}\end{array}$ & $\begin{array}{l}\operatorname{Tr}_{7} \\
\operatorname{Tr}_{8}\end{array}$ \\
\hline
\end{tabular}

,$+-=$ Resistance and sensitive to antibiotic, respectively.

\section{Chitinase activity}

The data presented in Table 5 showed that both transconjugants $\operatorname{Tr}_{2}$ and $\operatorname{Tr}_{6}$ appeared significant express of chitinase activity than the mid parents. Among the 10 transconjugants $\operatorname{Tr}_{2}$ and $\operatorname{Tr}_{6}$ produced purple colored zone. These results agreed with Bahar et al. (2012), who found that bacteria produced chitinase to be able to hydrolysis chitin polymer and produced metabolites to support their growth in the media supplemented with chitin as the only carbon and energy source without any nutrients. Whereas, Brurberg et al. (2001) decided that Serratia marcescens was an important bacteria with its efficient chitinase producer. However, Kamil et al . (2007) found that only $5 \%$ of 400 isolates (Bacillus sp.) appeared different clear zones sizes via chitinase activity. The chitin degrading bacteria used colloidal chitin as a sole source of carbon and 
energy which formed colonies surrounded by clear zone indicating chitinase production .

Table 5. Chitinase production by transconjugants resulted from the mating between $S m$ and $B t_{1}$.

\begin{tabular}{lcc}
\hline & \multicolumn{2}{c}{ Chitinase production } \\
\cline { 2 - 3 } Strains & $\begin{array}{c}\text { Diameter (cm) of } \\
\text { clear zones }\end{array}$ & $\begin{array}{c}\text { Diameter (cm) of the } \\
\text { purple colored zone }\end{array}$ \\
\hline$S m$ & 1.7 & 1.6 \\
$B t_{1}$ & 2.3 & 2.0 \\
Mid- parent & 2.0 & 1.8 \\
$\operatorname{Tr}_{1}$ & 0.0 & 0.0 \\
$\operatorname{Tr}_{2}$ & 1.7 & 1.3 \\
$\operatorname{Tr}_{3}$ & 0.0 & 0.0 \\
$\operatorname{Tr}_{4}$ & 0.0 & 0.0 \\
$\operatorname{Tr}_{5}$ & 0.0 & 0.0 \\
$\operatorname{Tr}_{6}$ & 1.6 & 1.5 \\
$\operatorname{Tr}_{7}$ & 0.0 & 0.0 \\
$\operatorname{Tr}_{8}$ & 0.0 & 0.0 \\
$\operatorname{Tr}_{9}$ & 0.0 & 0.0 \\
$\operatorname{Tr}_{10}$ & 0.0 & 0.0 \\
\hline F-test & $* *$ & $* *$ \\
LSD 0.05 & 0.12 & 0.10 \\
\multicolumn{1}{c}{0.01} & 0.16 & 0.13 \\
\hline
\end{tabular}

The results summarized in Table 6 appeared that some of recombinants ( $\operatorname{Tr}_{14}, \operatorname{Tr}_{19}$ and $\operatorname{Tr}_{20}$ ) reflected high express of chitinase activity if compared with the mid parents. These results agreed with Kuzu et al. (2012), who showed that Bacillus thuringiensis subsp. kurstaki showed its optimum activity of chitinase following three hours of incubation period . Reid and Ogrydziak (1981) found that maximum chitinase activity was obtained from $S$. marcescens grown in reese medium (with yeast extract) . Thamthiankul et al. (2001) found that Bacillus thuringiensis produced multiple chitinases with different molecular weights.

Table 6. Chitinase activity by transconjugants resulted from the mating between $\mathrm{Sm}$ and $\mathrm{Bt}_{2}$.

\begin{tabular}{lcc}
\hline \multirow{2}{*}{ Strains } & \multicolumn{2}{c}{ Halo zone of chitinase production } \\
\cline { 2 - 3 } & $\begin{array}{c}\text { Diameter of clear } \\
\text { zones(cm) }\end{array}$ & $\begin{array}{c}\text { Diameter of the } \\
\text { purple colored zone (cm) }\end{array}$ \\
\hline$S m$ & 1.7 & 1.6 \\
$B t_{2}$ & 1.9 & 2.1 \\
Mid - parent & 1.8 & 1.85 \\
$\operatorname{Tr}_{11}$ & 0.0 & 0.0 \\
$\operatorname{Tr}_{12}$ & 1.9 & 1.2 \\
$\operatorname{Tr}_{13}$ & 2.1 & 1.9 \\
$\operatorname{Tr}_{14}$ & 4.0 & 3.1 \\
$\operatorname{Tr}_{15}$ & 2.2 & 1.5 \\
$\operatorname{Tr}_{16}$ & 1.9 & 1.6 \\
$\operatorname{Tr}_{17}$ & 1.7 & 1.6 \\
$\operatorname{Tr}_{18}$ & 2.4 & 1.7 \\
$\operatorname{Tr}_{19}$ & 2.8 & 2.4 \\
$\operatorname{Tr}_{20}$ & 3.2 & 2.9 \\
\hline F-test & $* *$ & $* *$ \\
LSD 0.05 & 0.74 & 0.62 \\
\multicolumn{1}{c}{0.01} & 1.01 & 0.91 \\
\hline
\end{tabular}

The data presented in Table 7 showed that some transconjugants ( $\operatorname{Tr}_{33}, \operatorname{Tr}_{39}$ ) between $B L$ and $B t_{2}$ appeared significant diameter of halo zone which reflected increase in chitinase production above the mid - parents because of high performance of clear zone appeared from hydrolyzing the colloidal chitin . These results indicated that chitinase gene was present in the genome of $B t$ and $B L$. This agreed with Rey et al. (2004), who found that the genome sequence analysis of $B$. licheniformis also revealed the presence of chitinase gene. In addition, Dahiya et al. (2005) reported that chitinases isolated from different bacterial strains including Bacillus spp. produced multiple forms of chitinases with different molecular weights . Barboza - Corona et al. (1999) proposed that Cry proteins and chitinase from $B t$ species could have synergistic effects in improving $B t$ insecticidal activity. Furthermore, the potential of $B t$ chitinase might be used toward the control of plant pathogenic fungi .

Table 7. Chitinase activity by transconjugants resulted from the mating between $B L$ and $B t_{2}$.

\begin{tabular}{lcc}
\hline \multirow{2}{*}{ Strains } & \multicolumn{2}{c}{ Halo zone of chitinase production } \\
\cline { 2 - 3 } & $\begin{array}{c}\text { Diameter of clear } \\
\text { zones(cm) }\end{array}$ & $\begin{array}{c}\text { Diameter of the } \\
\text { purple colored zone }(\mathbf{c m})\end{array}$ \\
\hline$B L$ & 2.0 & 1.6 \\
$B t 2$ & 1.9 & 2.1 \\
Mid - parent & 1.95 & 1.85 \\
$\operatorname{Tr}_{31}$ & 0.0 & 0.0 \\
$\operatorname{Tr}_{32}$ & 0.0 & 0.0 \\
$\operatorname{Tr}_{33}$ & 2.9 & 3.5 \\
$\operatorname{Tr}_{34}$ & 0.0 & 0.0 \\
$\operatorname{Tr}_{35}$ & 0.0 & 0.0 \\
$\operatorname{Tr}_{36}$ & 1.2 & 2.1 \\
$\operatorname{Tr}_{37}$ & 1.9 & 1.8 \\
$\operatorname{Tr}_{38}$ & 0.0 & 0.0 \\
$\operatorname{Tr}_{39}$ & 2.1 & 3.5 \\
$\operatorname{Tr}_{40}$ & 0.0 & 0.0 \\
F-test & $* *$ & $* *$ \\
LSD 0.05 & 0.29 & 0.36 \\
\multicolumn{1}{c}{0.01} & 0.37 & 0.49 \\
\hline
\end{tabular}

The entomo pathogenic effect of Bacillus thuringiensis and their genetic recombinants after six days of treatments was summarized in Table 8. The results demonstrated that lethality rates were reached zero at $8 \times 10^{5} \mathrm{ppm}$ in response to the parental strains and their recombinants. The same trend was also showed by recombinants and their parents of all conjugations at the concentrations of 2,4 and $6 \times 10^{5}$ $\mathrm{ppm}$. This indicated that mortality was gradually increased to reached a maximum ratio after six days of treatments. Parental strains and their transconjugants significantly reduced the survival of larvae if compared with untreated ones. The accumulated mortality of larval stage of Tuta absoluta showed a time - response. This indicated that it is recommended to use bioinsecticides against the larval stage of Tuta absoluta for six days at least .These results are in harmony with Abdullah et al. (2014), who showed that the effect of five recombinants and their parents (B. thuringiensis and B. subtilis) on the $2^{\text {nd }}$ instar larvae of $T$. absoluta exhibited significantly higher effect by $B t$ in comparison with $B$. subtilis. The same authors also found that mortality percentages were reached to 87.6 and $91.6 \%$ after six days of treatments. In general, mortality rates were increased via the treatments with spores than without its. In addition, HernandezFernandez et al. (2010) found that ten Bt strains were increased larval lethality over the eight days following the 
crude extract application. Finney (1971) evalutated the hypothesis that suggested a linear correlation was obtained between doses and larval lethality. The same authors found $4.8 \mu \mathrm{g} \mathrm{ml}^{-1}$ crude protein extract of $B t$ strain produced $58.3 \%$, lethality on $T$. absoluta larvae, while the same doses of the reference strain $B t \mathrm{k}$ yielded lower mortality $(50.8 \%)$. Youssef and Hassan (2013) found that

Table 8. Effect of different concentrations of crystals and endospores resulted from recombinant bioinsecticides on larval survival after six days of treatment.

\begin{tabular}{|c|c|c|c|c|c|c|c|c|}
\hline \multirow[b]{3}{*}{ Treatments } & \multicolumn{8}{|c|}{ Bioinsecticide concentrations (ppm) $\times 10^{5}$} \\
\hline & \multicolumn{2}{|c|}{2} & \multicolumn{2}{|c|}{4} & \multicolumn{2}{|c|}{6} & \multicolumn{2}{|c|}{8} \\
\hline & $\begin{array}{c}\text { Number of } \\
\text { survival } \\
\text { larvae }\end{array}$ & $\begin{array}{c}\text { Mortality } \\
\%\end{array}$ & $\begin{array}{c}\text { Number of } \\
\text { survival } \\
\text { larvae }\end{array}$ & $\begin{array}{c}\text { Mortality } \\
\%\end{array}$ & $\begin{array}{c}\text { Number of } \\
\text { survival } \\
\text { larvae }\end{array}$ & $\begin{array}{c}\text { Mortality } \\
\%\end{array}$ & $\begin{array}{c}\text { Number of } \\
\text { survival } \\
\text { larvae }\end{array}$ & $\begin{array}{c}\text { Mortality } \\
\%\end{array}$ \\
\hline Control & 10 & 0 & 10 & 0 & 10 & 0 & 10 & 0 \\
\hline $\mathrm{Sm}$ & 1 & 90 & 1 & 90 & 0 & 100 & 0 & 100 \\
\hline $\mathrm{Bt}_{1}$ & 0 & 100 & 0 & 100 & 0 & 100 & 0 & 100 \\
\hline MP & 0.5 & 95 & 0.5 & 95 & 0 & 100 & 0 & 100 \\
\hline $\mathrm{Tr}_{1}$ & 1 & 90 & 0 & 100 & 1 & 90 & 0 & 100 \\
\hline $\operatorname{Tr}_{2}$ & 0 & 100 & 0 & 100 & 1 & 90 & 0 & 100 \\
\hline F- test & $* *$ & & $* *$ & & $* *$ & & $* *$ & \\
\hline LSD 0.05 & 1.64 & & 1.13 & & 0.90 & & 0.53 & \\
\hline 0.01 & 2.43 & & 1.24 & & 1.41 & & 0.74 & \\
\hline Control & 10 & 0 & 10 & 0 & 10 & 0 & 10 & 0 \\
\hline $\mathrm{Sm}$ & 1 & 90 & 1 & 90 & 0 & 100 & 0 & 100 \\
\hline $\mathrm{Bt}_{2}$ & 0 & 100 & 0 & 100 & 0 & 100 & 0 & 100 \\
\hline MP & 0.5 & 95 & 0.5 & 95 & 0 & 100 & 0 & 100 \\
\hline $\mathrm{Tr}_{3}$ & 1 & 90 & 0 & 100 & 1 & 90 & 0 & 100 \\
\hline $\operatorname{Tr}_{4}$ & 0 & 100 & 0 & 100 & 1 & 90 & 0 & 100 \\
\hline F- test & $* *$ & & $* *$ & & $* *$ & & $* *$ & \\
\hline LSD 0.05 & 1.50 & & 1.23 & & 1.53 & & 0.70 & \\
\hline 0.01 & 2.12 & & 1.71 & & 2.20 & & 1.14 & \\
\hline
\end{tabular}

Table 8. Continued.

\begin{tabular}{|c|c|c|c|c|c|c|c|c|}
\hline \multirow{3}{*}{ Treatments } & \multicolumn{8}{|c|}{ Bioinsecticide concentrations (ppm) $\times 10^{5}$} \\
\hline & \multicolumn{2}{|l|}{2} & \multicolumn{2}{|c|}{4} & \multicolumn{2}{|c|}{6} & \multicolumn{2}{|l|}{8} \\
\hline & $\begin{array}{c}\text { Number of } \\
\text { survival larvae }\end{array}$ & $\begin{array}{c}\text { Mortality } \\
\%\end{array}$ & $\begin{array}{c}\text { Number of } \\
\text { survival larvae }\end{array}$ & $\begin{array}{c}\text { Mortality } \\
\%\end{array}$ & $\begin{array}{c}\text { Number of } \\
\text { survival larvae }\end{array}$ & $\begin{array}{c}\text { Mortality } \\
\%\end{array}$ & $\begin{array}{c}\text { Number of } \\
\text { survival larvae }\end{array}$ & $\begin{array}{c}\text { Mortality } \\
\%\end{array}$ \\
\hline Control & 10 & 0 & 10 & 0 & 10 & 0 & 10 & 0 \\
\hline $\mathrm{Bl}$ & 0 & 100 & 0 & 100 & 0 & 100 & 0 & 100 \\
\hline $\mathrm{Bt}_{1}$ & 0 & 100 & 0 & 100 & 0 & 100 & 0 & 100 \\
\hline MP & 0 & 100 & 0 & 100 & 0 & 100 & 0 & 100 \\
\hline $\operatorname{Tr}_{5}$ & 0 & 100 & 0 & 100 & 0 & 100 & 0 & 100 \\
\hline $\operatorname{Tr}_{6}$ & 1 & 90 & 1 & 90 & 1 & 90 & 1 & 90 \\
\hline F- test & $* *$ & & $* *$ & & $* *$ & & $* *$ & \\
\hline LSD 0.05 & 0.91 & & 0.70 & & 0.52 & & 0.52 & \\
\hline 0.01 & 1.34 & & 1.12 & & 0.71 & & 0.71 & \\
\hline Control & 10 & 0 & 10 & 0 & 10 & 0 & 10 & 0 \\
\hline $\mathrm{Bl}$ & 0 & 100 & 0 & 100 & 0 & 100 & 0 & 100 \\
\hline $\mathrm{Bt}_{2}$ & 0 & 100 & 0 & 100 & 0 & 100 & 0 & 100 \\
\hline MP & 0 & 100 & 0 & 100 & 0 & 100 & 0 & 100 \\
\hline $\mathrm{Tr}_{7}$ & 0 & 100 & 1 & 90 & 0 & 100 & 0 & 100 \\
\hline $\mathrm{Tr}_{8}$ & 0 & 100 & 0 & 100 & 0 & 100 & 0 & 100 \\
\hline F- test & $* *$ & & $* *$ & & $* *$ & & $* *$ & \\
\hline LSD 0.05 & 0.82 & & 0.90 & & 0.51 & & 0.51 & \\
\hline 0.01 & 1.21 & & 1.32 & & 0.70 & & 0.70 & \\
\hline
\end{tabular}

*, ** = Significance at 0.05 and 0.01 levels of probability, respectively .

\section{Larval weight}

As shown in Table 9 the results appeared that there were a significant differences between bioinsecticides in larval weight at all concentrations used. Most of $B t$ bioinsecticides significantly reduced larval weight as compared with that feeding on untreated diet. This agreed with Yee and Toscano (1998), who found a decrease in larval weight of third and fifth instars of $S$. exigua exposed to lettuce leaf disks contaminated with spinosad. commercial product of B. thruingiensis var. kurstaki was highly insecticidal activity on the different larval stages of T. absoluta. Roh et al. (2007) reported that the potential of commercial biocide B. thuringiensis subsp kurstaki in controlling insects of economic importance is well known as a key tool of Integrated Pest Management Programs. 
Table 9 . Effect of different concentrations of crystals and endospores resulted from recombinant bioinsecticides on larval weight after six days.

\begin{tabular}{|c|c|c|c|c|}
\hline \multirow{2}{*}{ Treatments } & \multicolumn{4}{|c|}{ Bioinsecticide concentrations ( ppm ) $\times 10^{5}$} \\
\hline & 2 & 4 & 6 & 8 \\
\hline Control & 3.9 & 3.9 & 3.9 & 3.9 \\
\hline Sm & 0.1 & 0.1 & 0.0 & 0.0 \\
\hline$B t_{l}$ & 0.0 & 0.0 & 0.0 & 0.0 \\
\hline MP & 0.05 & 0.05 & 0.0 & 0.0 \\
\hline $\operatorname{Tr}_{1}$ & 0.1 & 0.0 & 0.3 & 0.0 \\
\hline $\operatorname{Tr}_{2}$ & 0.0 & 0.0 & 0.3 & 0.0 \\
\hline F- test & ** & $* *$ & $* *$ & $* *$ \\
\hline LSD 0.05 & 0.60 & 0.16 & 0.65 & 0.59 \\
\hline 0.01 & 0.84 & 0.22 & 0.94 & 0.86 \\
\hline $\mathrm{Sm}$ & 0.1 & 0.1 & 0.0 & 0.0 \\
\hline $\mathrm{Bt}_{2}$ & 0.0 & 0.0 & 0.0 & 0.0 \\
\hline MP & 0.05 & 0.05 & 0.0 & 0.0 \\
\hline $\mathrm{Tr}_{3}$ & 0.1 & 0.0 & 0.1 & 0.0 \\
\hline $\mathrm{Tr}_{4}$ & 0.0 & 0.0 & 0.1 & 0.0 \\
\hline F- test & $* *$ & $* *$ & $* *$ & $* *$ \\
\hline LSD 0.05 & 0.60 & 0.60 & 0.07 & 0.59 \\
\hline 0.01 & 0.84 & 0.85 & 0.14 & 0.86 \\
\hline$\overline{B l}$ & 0.0 & 0.0 & 0.0 & 0.0 \\
\hline$B t_{l}$ & 0.0 & 0.0 & 0.0 & 0.0 \\
\hline MP & 0.0 & 0.0 & 0.0 & 0.0 \\
\hline $\operatorname{Tr}_{5}$ & 0.0 & 0.0 & 0.0 & 0.0 \\
\hline $\operatorname{Tr}_{6}$ & 0.4 & 0.1 & 0.1 & 0.1 \\
\hline F- test & $* *$ & $* *$ & $* *$ & $* *$ \\
\hline LSD 0.05 & 0.58 & 0.59 & 0.58 & 0.58 \\
\hline 0.01 & 0.84 & 0.85 & 0.84 & 0.84 \\
\hline$\overline{B l}$ & 0.0 & 0.0 & 0.0 & 0.0 \\
\hline$B t_{2}$ & 0.0 & 0.0 & 0.0 & 0.0 \\
\hline MP & 0.0 & 0.0 & 0.0 & 0.0 \\
\hline $\operatorname{Tr}_{7}$ & 0.0 & 0.1 & 0.0 & 0.0 \\
\hline $\operatorname{Tr}_{8}^{\prime}$ & 0.0 & 0.0 & 0.0 & 0.0 \\
\hline F- test & $* *$ & $* *$ & $* *$ & $* *$ \\
\hline LSD 0.05 & 0.60 & 0.07 & 0.59 & 0.59 \\
\hline 0.01 & 0.87 & 0.09 & 0.86 & 0.86 \\
\hline
\end{tabular}

As shown from the results diagrammatic in Figure 1 the larval weight gain of Tuta absoluta through six days of feeding on different concentrations of recombinant bioinsecicides was decreased gradually through the six days . The results appeared a strong reduction in larval weight after three days of feeding on $B t$ - treated leaves The most efficient decrease in larval weight gain of Tuta absoluta was shown in response to the concentration of $8 \mathrm{x}$ $10^{5} \mathrm{ppm}$. These results are in harmony with Jamoussi et al. (2013), who demonstrated that B. thuringiensis $\mathrm{KS}$ is a promising strain that produced more efficient $\delta$-endotoxins against $T$. absoluta than the reference strain HD1 already largely used in biological control .The result also agreed with Gobbi et al. (2000), who revealed that the concentration of $100 \mathrm{mg}$ active ingredient (AI) $/ \mathrm{Kg}$ diet of tubufenozide caused a weight reduction of 55 and $74 \%$ in fourth instars of Mythimna unipuata and S. littoralis, respectively, after $48 \mathrm{~h}$ of treatment . Moreover, Zhao et al. (1999) found that transgenic plants of tabacco via two insecticidal genes ( cry $1 A$ and $C p T 1$ ) could significantly delay resistance developed in $H$. armigera if compared with one gene (cry Al ) transgenic plants. The effects caused by recombinant $B t$ are very important from a practical point of view because larval feeding damage to crop would be suppressed, leading to reduced offspring, as well as, the insect population as a consequence can be still below a level of economic loss.
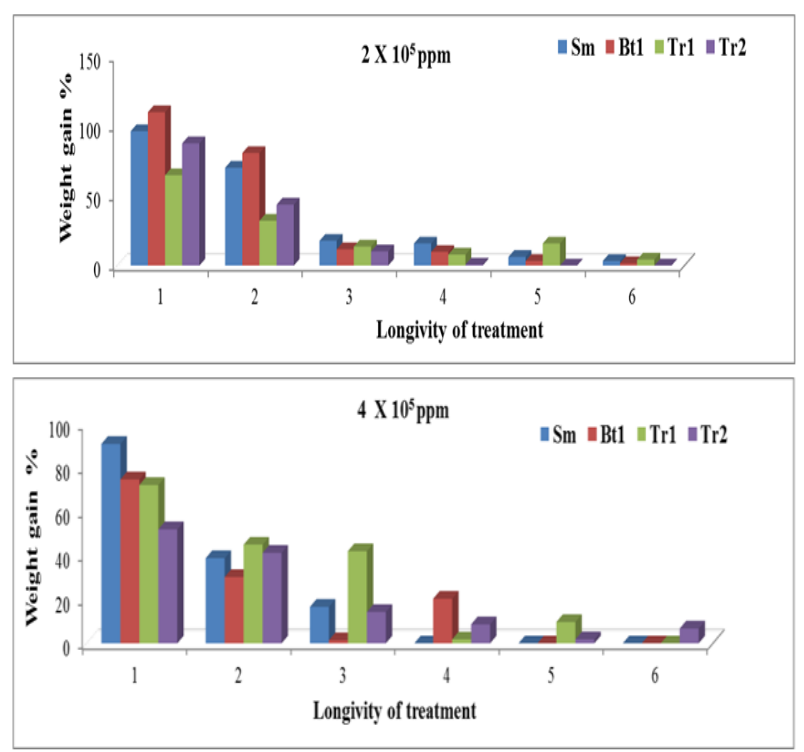

Figure 1. Larval weight of Tuta absoluta gain treated with different concentrations of Bt toxins produced by recombinants obtained from the mating between $\mathrm{Sm} \times \mathrm{Bt}$.

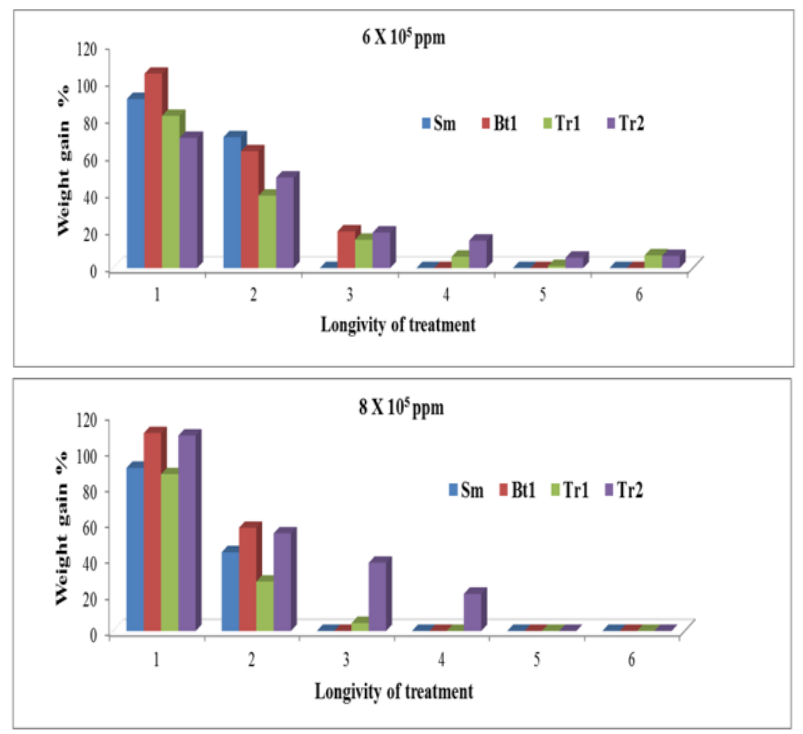

Figure 1. Continued.

As shown in Figure 2 the weight gain of Tuta absoluta larvae was more reduced through six days of feeding. The results appeared a strong reduction in larval weight by $B t$ recombinants after four and two days of consumption on $B t$ - treated leaves with the concentrations of $2 \times 10^{5} \mathrm{ppm}$ and $4 \times 10^{5} \mathrm{ppm}$, respectively. Also a strong reduction in the gain of larval weight was shown after three days of feeding on $B t$ - treated leaves with the concentrations of $6 \times 10^{5} \mathrm{ppm}$ and $8 \times 10^{5} \mathrm{ppm}$. These results are in harmony with Habib and Amaral (1985), who found that the wet table powder formation of $B t$ var . kurstaki with a flow rate of $20 \mathrm{~L} /$ ha gave best control against the larvae of Anticarisa gammatalis on soybean in Barzil ,as well as, larvae stop feeding within a little hours of ingesting $B t$ protein. Probably the effect of $B t$ on feeding was related to the damage in midgut tissues and to gut paralysis . The effect of $B t$ as shown in this study is useful in terms of preventing economic loss due to defoliation and damage to inner tomato plant tissues. However, Wiwat et 
al. (2000) found that the toxicity against diamondback moth larvae ( $P$. xyostella) increased with using $B$. thuringiensis which produced higher amount of chitinase if compared with other $B t$ strains which do not produced chitinase or produce little amount. In addition, Bravo et al. (2007) found that $B t$ strains synthesize $\delta$-endotoxins at the stage of sporulation in the stationary growth phase as parasporal crystalline inclusions . Once ingested by pests, these delta endotoxin are solubilized in the midgut, then the toxins are proteolytically activated by midgut proteases which bind to specific receptors distributed in the insect cell membrane, leading to cell disruption and insect mortality.
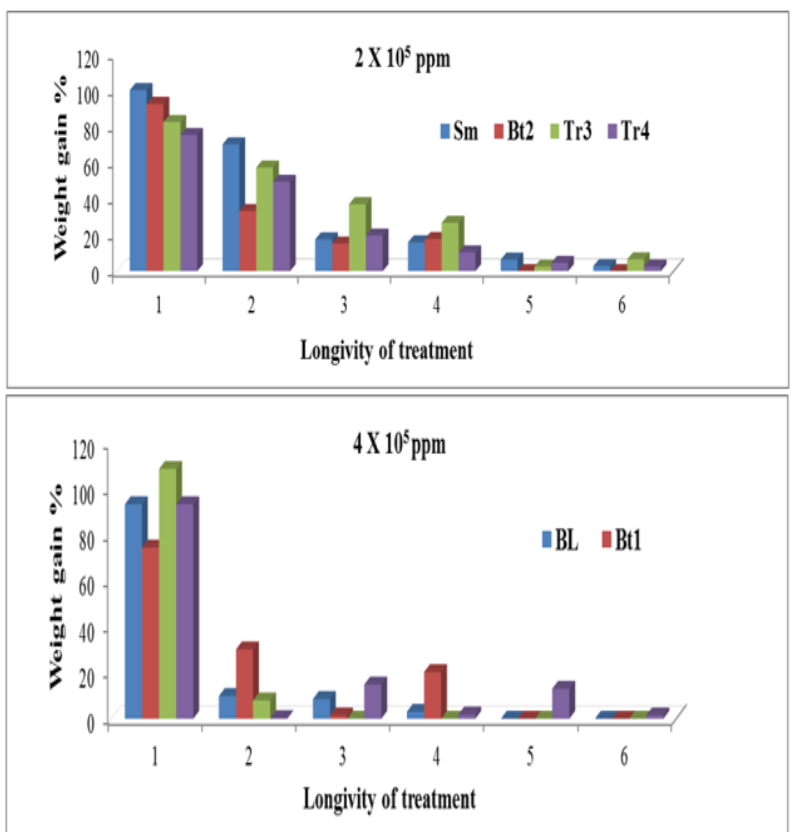

Figure 2. Larval weight gain of Tuta absoluta treated with different concentrations of crystal toxins produced by recombinants obtained from the mating between $B L$ against $\mathrm{Bt}_{1}$.
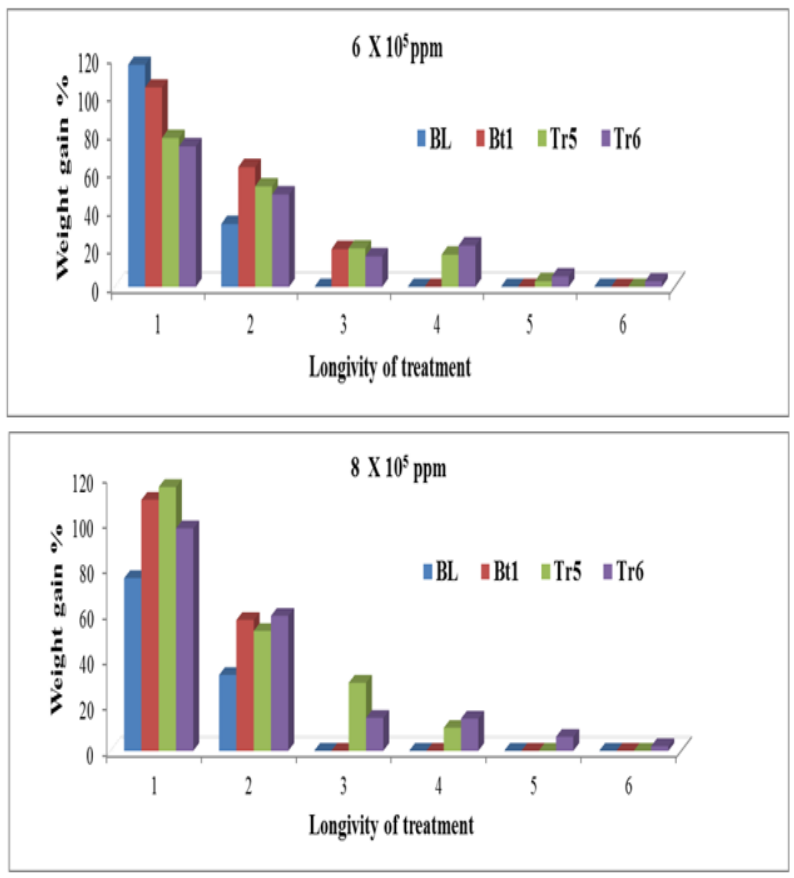

Figure 2. Continued.
Correlation between the time of feeding and larval weight

As shown from the results diagrammatic in Figure 3 that the reduction in larval weight showed a time response, in contrast with the increased in larval weight in the control group which showed also a time - response, because they were fed on diet non-containing $B t-$ bioinsecticides. This indicated that $B t-$ treated leaves may affect to stop the feeding of larval stage leading to reduced the larval weight in comparison to the control. Strong deterrent effects on larval weight was shown in Bttreatment larvae in relation to the control group. The results appeared a direct relationship between the feeding time and larval weight. This may due to the larvae preferred the control food than $B t$ - treated diet. The control food stimulated the food intake than Bt- treated food which showed a deterrent effect, as well as, decreased the larval growth and consequently reduced the larval weight These results agreed with El- Adl et al. (2016), who obtained that most bioinsecticides significantly reduced larval weight in untreated diet due to chronic toxicity . Bt treated diet was influencing the larval weight due to the antifeedant effect which reduced feeding and food ingestion. Even if the $B t$ - treated diet did not affect the feeding deterrence of Tuta absoluta larvae, they decreased the larval weight due to the lower conversion efficiency of the ingested food. These are in harmony agreed with Chandrasekaran et al. (2012), who found that chitinase exposed larvae reduced body weight and did not still survive as a long period if compared with the controls.

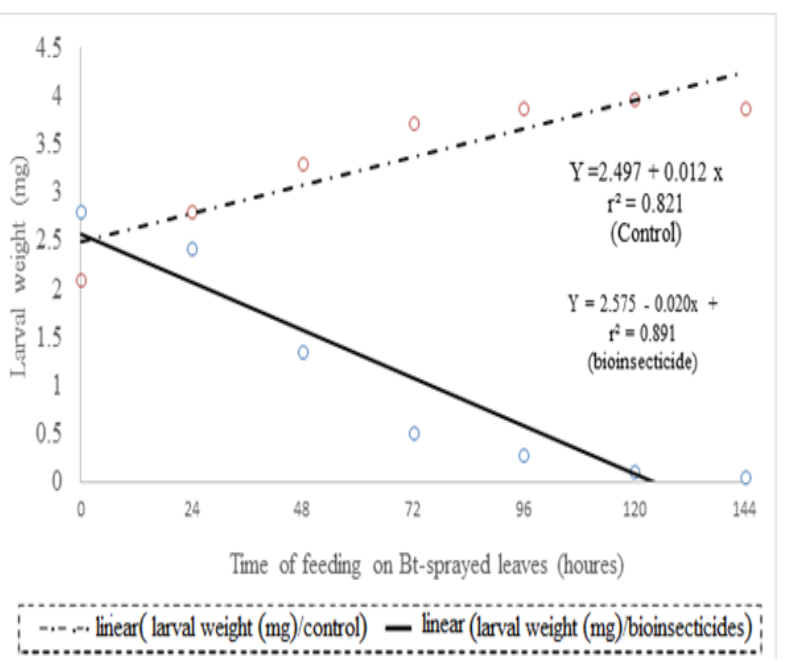

Figure 3. Regression line of recombinant bioinsecticides affected on larval weight in relation to untreated diet during six days of feeding on $B t$ - treated leaves .

In addition, $\mathrm{Yu}$ et al. (2013) obtained that surviving larvae feeding on $B t$ treated soybean weighted less than that feeding on non-Bt soybean. Dutton et al. (2003) found negative effects on survival, development and weight of $C$. carnea larvae when feeding on Btsprayed plants.

\section{Effect of $B t$ concentration}

As shown from the results presented in Figure 4 that the decreased in larval weight showed a dose response. This indicated that there were a direct 
relationship between doses of Bt- bioinsecticides and decreased in larval weight as a consequence of feeding deterrence. The results obtained herein indicated a strong deterrent effects of $B t$ - bioinsecticides against larvae of Tuta absoluta. This reflected a negative effect on larval development and the conversion of the ingested and digested food. Conversion of the ingested food was mostly lower in $B t-$ treated larvae if compared with the control group . The low metabolism of food caused prolongation of the larval development and chronic toxicity. Generally, larval growth suppress was caused by the antifeedant effect which reduced food ingestion or even prevented the larval growth at the higher doses because of chronic toxicity against $T$. absoluta. These results agreed with Gonzalez-Cabrera et al. (2011), who evaluated the effect of Bacillus thuringiensis on T. absoluta which showed high efficacy in reducing the damage at high infestation levels if compared with non-treated group. On the other hand, Azambuja et al. (2015) found that after five days of feeding all the larvae fed on $B t$ soybean leaves had died, while $95 \%$ of the control larvae survived. In addition , Hafsi et al. (2012) found that B. thuringiensis had antifeedant effect on T. absoluta leading to be used instead of synthetic chemical insecticides.

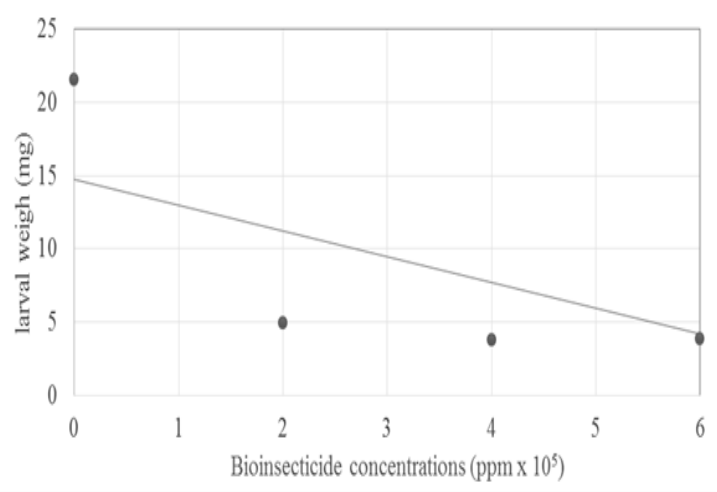

Figure 4 . Larval weight regression line of different $B t$ concentrations treated grubs .

However, Miyasono et al. (1994) showed that toxin -free spores did not kill larvae, but spores increased the toxin of Bt kurstaki crystal against larvae from a susceptible strain of diamondback moth. Furthermore, Dulmage and Martinez (1973) found that the sub- lethal doses of the entomopatogenic microbe had significant effects on insect pest development .

\section{Toxicity index}

Data summarized in Table 10 appeared that the mean of larval weight after six days of feeding on $\mathrm{Bt}$ treated leaves was greatly decreased by the following bioinsecticides ; $B t_{2}, B l, \mathrm{Tr}_{8}, \mathrm{Tr}_{1}, \mathrm{Tr}_{7}$ and $\mathrm{Tr}_{4}$. The larval weight after six days of treatments was more decreased when the larvae feed on Bt-treated leaves. This indicated that $B t$ - treatment have antifeedant activity. Strong deterrent effects of $B t$ treatments against larvae of Tuta absoluta was observed by $B t_{2}$ and $B l$ followed by the recombinants $\operatorname{Tr}_{8}, \operatorname{Tr}_{1}, \operatorname{Tr}_{7}$ and $\operatorname{Tr}_{4}$ which appeared a lower body weight of larvae than all other $B t$ treatments due to feeding deterrence. The recombinant $\operatorname{Tr}_{8}$ treaed diet appeared higher feeding deterrence on Tuta absoluta larvae than all other recombinants. Also the results showed that the mean of toxicity index after six days of feeding on $B t$ treated leaves was greatly increased by the following bioinsecticides; $\mathrm{Tr}_{8}, \mathrm{Tr}_{7}, \mathrm{Tr}_{4}, B l, B t_{1}$ and $\operatorname{Tr}_{1}$. The recombinant $\operatorname{Tr}_{8}$ appeared $66 \%$ toxicity index than other recombinants. This indicated that a lower concentration of this recombinant requires to suppress the growth and development of $66 \%$ of larval population. This agreed with Stanley-Horn et al. (2001), who found that the average body weights of larvae $(1.7 \mathrm{mg})$ feeding on leaves treated with $B t$ hybrids were significantly less than weights of larvae $(2.0 \mathrm{mg})$ on the other $B t$ hybrids combined. Hellmich et al. (2001) found less weight gain at doses below 5-10 grains per $\mathrm{cm}^{2}$ after a four - day treatment period. Meissle et al. (2009) found that after four days of feeding on $B t$ maize , body weight gain was significantly lower than in the control mazie group. Romeis et al. (2009) found that the insect larvae feeding on $B t$ plants may result in decreased movement due to sublethal damage or, in contrast, the higher activity of larvae may be due to search for better food. Prasifka et al. (2007) found that larvae treated with $B t$ anthers feeding less and gained less body weight than those exposed to non- $B t$ anthers or no anthers, as well as, there was a $21 \%$ decreased in body weight gain when larvae were exposed to $B t$ anthers. In addition, Singh et al. (2008) showed that the larvae of $C$. medinalis reared on untreated potted rice plants after $24 \mathrm{hrs}$ of feeding on $\mathrm{Bt}$ treated plants increased larval duration, as well as, decreased the weight of larvae. Binning et al. (2014) found that pests treated with non-Bt and $B t$-RW maize showed weight changed and stop feeding which leading to losses of weight at 9 and 13 days

\section{Feeding deterrence index}

As shown from the results diagrammatic in Figure 5 the feeding detterence index of Tuta absoluta larvae was increased in response to $B t$ - treated leaves. Moreover, the feeding detterrence index was still increased to reached $98 \%$ or more when the larvae were feeding on $B t_{1}, B t_{2}, B l$, $\operatorname{Tr}_{5}$ and $\operatorname{Tr}_{7}-$ treated leaves . These results indicated that progressive feeding on $\mathrm{Bt}$ - treated leaves leading larvae to reduce the feeding gradually untill completely stopped. In addition, $B t$ recombinants , as well as, their parental strains has a great potential effect for controlling and suppress the feeding of larval stage on the host plants. These results agreed with Jyoti et al. (1996), who found that the larvae survived seven days at the exposure to $B t$-treated leaves showed a reduced leaf consumption of up to $85 \%$. In addition , Binod et al. (2007) found that biocontrol assay on Helicoverpa armigera appeared that the culture filtrate is an important antifeedant because it was decreased the consumption rate and larval body weight. Singh et al. (2007) observed $100 \%$ mortality of larvae after $72 \mathrm{~h}$ of feeding on Bt sprayed leaves. El- Adl et al. (2016) found a strong reduction in larval weight after feeding on $B t-$ treated leaves for 240 hours. Pineda et al. (2007) found a strong decreased in larval body weight in fourth instars of S. littoralis after $48 \mathrm{~h}$ of consumption on Capsicum annum $L$. treated leaves with methoxyfenozide either by dipping or spraying technique. On the other hand, Smagghe et al. (1997) demonstrated that the larvae treated with tebufenozide could suffer from gut modification which leading larvae to suppress feeding and lost their weight as consequence. 
Table 10 . Larval weight and toxicity index through six days of feeding on Bt-treated leaves.

\begin{tabular}{|c|c|c|c|c|c|c|c|c|c|c|c|c|c|c|c|}
\hline \multirow{3}{*}{ Bioinsecticides } & \multicolumn{12}{|c|}{ Time (hours) } & \multirow{3}{*}{$\begin{array}{c}\text { Genera } \\
\text { I mean } \\
\text { Weight } \\
(\mathrm{mg})\end{array}$} & \multirow{3}{*}{ TI } & \multirow{3}{*}{$\begin{array}{c}\text { Mean } \\
\text { of } \\
\text { FDI\% }\end{array}$} \\
\hline & \multicolumn{2}{|c|}{24} & \multicolumn{2}{|c|}{48} & \multicolumn{2}{|c|}{72} & \multicolumn{2}{|c|}{96} & \multicolumn{2}{|c|}{120} & \multicolumn{2}{|c|}{144} & & & \\
\hline & $\begin{array}{l}\text { Weight } \\
\text { (mg) }\end{array}$ & TI & $\begin{array}{c}\text { Weight } \\
\text { (mg) }\end{array}$ & TI & $\begin{array}{c}\text { Weight } \\
\text { (mg) }\end{array}$ & TI & $\begin{array}{l}\text { Weight } \\
\text { (mg) }\end{array}$ & TI & $\begin{array}{l}\text { Weight } \\
\text { (mg) }\end{array}$ & TI & $\begin{array}{c}\text { Weight } \\
\text { (mg) }\end{array}$ & TI & & & \\
\hline Control & 2.80 & 0.72 & 3.30 & 0.26 & 3.73 & 0.06 & 3.9 & 0.02 & 4.0 & 0.01 & 3.9 & 0.01 & 3.60 & 0.18 & 0.0 \\
\hline Sm & 2.62 & 0.77 & 1.83 & 0.46 & 0.37 & 0.62 & 0.23 & 0.34 & 0.15 & 0.13 & 0.05 & 0.4 & 0.88 & 0.45 & 65 \\
\hline$B t_{1}$ & 2.80 & 0.73 & 1.93 & 0.44 & 0.4 & 0.58 & 0.10 & 0.8 & 0.02 & 1.00 & 0.00 & 0.00 & 0.87 & 0.59 & 67 \\
\hline MP & 2.71 & 0.75 & 1.88 & 0.45 & 0.38 & 0.60 & 0.16 & 0.57 & 0.08 & 0.56 & 0.02 & 0.2 & 0.87 & 0.52 & 66 \\
\hline $\operatorname{Tr}_{1}$ & 2.10 & 0.96 & 1.20 & 0.71 & 0.62 & 0.37 & 0.18 & 0.44 & 0.18 & 0.11 & 0.10 & 0.2 & 0.73 & 0.46 & 68 \\
\hline $\mathrm{Tr}_{2}$ & 2.20 & 0.92 & 1.55 & 0.55 & 0.72 & 0.32 & 0.40 & 0.20 & 0.08 & 0.25 & 0.08 & 0.25 & 0.84 & 0.41 & 65 \\
\hline Sm & 2.62 & 0.77 & 83 & 0.46 & 0.37 & 0.62 & 0.23 & 0.34 & 0.15 & 0.13 & 0.05 & 0.4 & 0.88 & 0.45 & 65 \\
\hline$B t_{2}$ & 2.30 & 0.88 & 0.85 & 1.00 & 0.37 & 0.62 & 0.35 & 0.23 & 0.00 & 0.00 & 0.00 & 0.00 & 0.65 & 0.45 & 72 \\
\hline MP & 2.46 & 0.82 & 1.34 & 0.73 & 0.37 & 0.62 & 0.29 & 0.28 & 0.07 & 0.06 & 0.025 & 0.2 & 0.76 & 0.45 & 68.5 \\
\hline $\operatorname{Tr}_{3}$ & 2.45 & 0.82 & 1.70 & 0.50 & 0.82 & 0.28 & 0.63 & 0.13 & 0.2 & 0.1 & 0.05 & 0.4 & 0.98 & 0.37 & 60 \\
\hline $\mathrm{Tr}_{4}$ & 2.27 & 0.89 & 1.17 & 0.73 & 0.63 & 0.37 & 0.32 & 0.25 & 0.05 & 0.4 & 0.02 & 1.00 & 0.74 & 0.60 & 68 \\
\hline$B l$ & 2.63 & 0.77 & 1.10 & 0.77 & 0.23 & 1.00 & 0.08 & 1.00 & 0.00 & 0.00 & 0.00 & 0.00 & 0.67 & 0.59 & 73 \\
\hline$B t_{1}$ & 2.80 & 0.73 & 1.93 & 0.44 & 0.4 & 0.58 & 0.10 & 0.8 & 0.02 & 1.00 & 0.00 & 0.00 & 0.87 & 0.59 & 67 \\
\hline MP & 2.71 & 0.75 & 1.51 & 0.61 & 0.32 & 0.79 & 0.09 & 0.9 & 0.01 & 0.5 & 0.00 & 00 & 0.77 & 0.59 & 70 \\
\hline $\operatorname{Tr}_{5}$ & 2.70 & 0.75 & 1.20 & 0.71 & 0.55 & 0.42 & 0.42 & 0.19 & 0.03 & 0.66 & 0.00 & 00 & 0.82 & 0.45 & 67 \\
\hline $\operatorname{Tr}_{6}$ & 2.03 & 1.00 & 1.45 & 0.58 & 0.85 & 0.27 & 0.52 & 0.15 & 0.42 & 0.04 & 0.17 & 0.11 & 0.91 & 0.35 & 61 \\
\hline$B l$ & 2.63 & 0.77 & 1.10 & 0.77 & 0.23 & 1.00 & 0.08 & 1.00 & 0.00 & 0.00 & 0.00 & 0.00 & 0.67 & 0.59 & 73 \\
\hline$B t_{2}$ & 2.30 & 0.88 & 0.85 & 1.00 & 0.37 & 0.62 & 0.35 & 0.23 & 0.00 & 0.00 & 0.00 & 0.0 & 0.65 & 0.45 & 72 \\
\hline MP & 2.47 & 0.82 & 0.97 & 0.88 & 0.30 & 0.81 & 0.21 & 0.62 & 0.00 & 0.00 & 0.00 & 0.00 & 0.66 & 0.52 & 72.5 \\
\hline $\operatorname{Tr}_{7}$ & 2.45 & 0.82 & 1.23 & 0.69 & 0.47 & 0.49 & 0.13 & 0.61 & 0.13 & 0.15 & 0.02 & 1.00 & 0.74 & 0.62 & 69 \\
\hline $\operatorname{Tr}_{8}$ & 2.53 & 0.80 & 1.17 & 0.73 & 0.23 & 1.00 & 0.10 & 0.8 & 0.03 & 0.66 & 0.00 & 0.00 & 0.68 & 0.66 & 72 \\
\hline F-test & $* *$ & $* *$ & $* *$ & $* *$ & $* *$ & $* *$ & $* *$ & $* *$ & $* *$ & $* *$ & $* *$ & $* *$ & $* *$ & $* *$ & $* *$ \\
\hline LSD & 2.08 & 3.33 & 3.02 & 3.02 & 2.18 & 2.63 & 4.38 & 3.94 & 1.64 & 1.46 & 4.53 & 4.53 & 1.57 & 3.79 & 4.13 \\
\hline & 2.81 & 4.49 & 4.07 & 4.07 & 2.95 & 3.54 & 5.93 & 5.33 & 2.21 & 2.21 & 6.09 & 6.09 & 2.13 & 5.11 & 5.56 \\
\hline
\end{tabular}

TI = Toxicity index

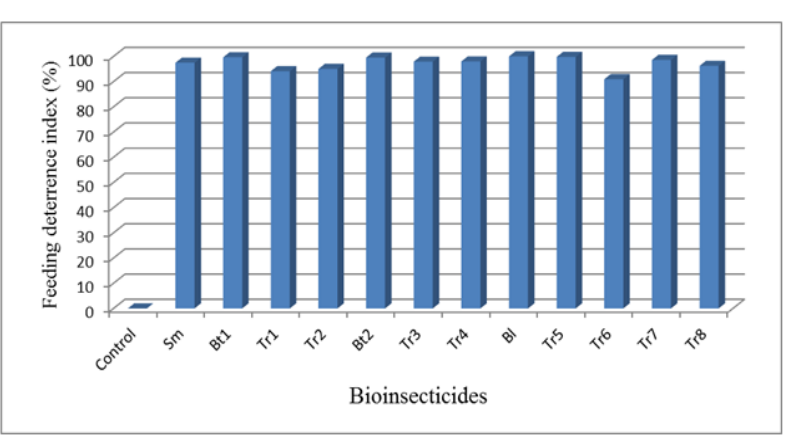

Figure 5 . The feeding deterrence index of $B t$-treated diet against Tuta absoluta larvae after 144 houres.

In conclusion, the results revealed that transferring chitinase gene from Serratia marcescens and Bacillus licheniforms to $B t$ strains has improved the toxicity of $B t$ against $T$. absoluta . Modified $B t$ strains aquired two mode of actions against insect pests. The first one through crystal toxins formation which induced pores in insect's mid-gut causing insect death. The second mechanism through increasing the production of chitinase enzyme which degrade the cuticle layer in insect's body resulting in insect dehydration leading to mortality.

\section{REFERENCES}

Abbott, W. S. 1925. A method of computing the effectiveness of an insecticide. J. Econ. Entomol, 18: $265-267$.

Abdullah, R. R.; N. A. Sukar and N.M. Ghanim . 2014. Improving the efficiency of Bacillus thuringiensis against insects of different feeding habits by plasmid transfer technique . Life Science Journal,11(3) 308-318.
Agrawal, A. and A.S. Kotasthane .2012. Chitinolytic assay of indigenous Trichoderma isolates collected from different geographical locations of Chhattisgarh in Central India. Springer Plus, 1(1):2-10.

Aronson, A. I. and W. Beckman. 1987. Transfer of chromosomal genes and plasmids in Bacillus thuringiensis. Appl. Environ. Microbiol, 53:15251530.

Azambuja, R.; P.E. Degrande; S. Rod; E. P. Souza and C. E. C. Gomes.2015. Effect of Bt Soybean on Larvae of Helicoverpa armigera (Hübner) (Lepidoptera: Noctuidae), 7(8) 90-96.

Bahar, A. A.; K. Sezen; Z. Demirbağ and R. Nalçacioglu. 2012. The relationship between insecticidal effects and chitinase activities of Coleopteran-originated entomopathogens and their chitinolytic profile. Ann Microbiol, 62:647-653.

Barboza-Corona, J. E.; J. C. Contreras; R. VelazquezRobledo; M. Bautista-Justo; M. GómezRamirez; R. Cruz-Camarillo and J. E. Ibarra. 1999. Selection of chitinolytic strains of Bacillus thuringiensis. Biotechnol Letters, 21:1125-112

Bautista, J.R. and F. G. Teves.2013. Antibiotic susceptibility testing of isolated Bacillus thuringiensis from three soil types around Iligan City, Philippines. African Journal of Microbiology Research , 7(8), 678-682.

Bernhard, K.; H. Schempf and W.Goebe. 1987. Bacteriocin and antibiotic resistance plasmids in Bacillus cereus and Bacillus subtilis. Journal of Bacteriology, 133: 897-903.

Bhattacharya, D.; A. Nagpure and R.K. Gupta .2007. Bacterial chitinases: properties and potential. Crit Rev Biotechnol, 27: 21-28. 
Binning, R. R .; J. Coats; X. Kongc and R. L. Hellmichd. 2014. Susceptibility to $B t$ proteins is not required for Agrotis ipsilon aversion to Bt maize. Pest Manag Sci, 71: 601-606.

Binod, P.; R.K. Sukumaran; S.V. Shirke; J.C. Rajput and A. Pandey .2007. Evaluation of fungal culture filtrate containing chitinase as a biocontrol agent against Helicoverpa armigera. Journal of Applied Microbiology ISSN 1364-5072.

Bravo, A.; S. S. Gill and M. Soberon.2007. Mode of action of Bacillus thuringiensis Cry and Cyt toxins and their potential for insect control. Toxicon , 49: 423435.

Brurberg, M. B.; B. Synstad; S. S. Klemsdal; D. M. F. van Aalten; L. Sundheim and V .G. H. Eijsink .2001. Chitinases from Serratia marcescens. Recent Res Dev Microbiol, 5:187-204.

Caceres, S .1992. La polilla del tomate en Corrientes. Biologa y control. Estaci n Experimental Agropecuaria Bella Vista, INTA, 11: 1-42.

Cely, L.; F. Cantor; D. Rodriguez and J. Cure .2006. Niveles de danos ocasionados por diferentes densidades de Tuta absoluta (Lepidoptera: Gelechiidae) en tomate bajo invernadero. En: Resúmenes XXXIII Congreso de Entomologia Socolen, julio 26-28, Manizales. $111 \mathrm{p}$.

Chandrasekaran, R; K. Revathi; S. Nisha; S A. Kirubakaran ; S. Sathish Narayanan and S. SenthilNathan .2012. Physiological effect of chitinase purified from Bacillus subtilis against the tobacco cutworm Spodoptera litura (Fab.). Pest Biochem Physiol, 104(1):65-71

Collins,C. H. and P. M. Lyne. 1985. Microbiological Methods. $5^{\text {th }}$ Edition. Butterworth and Co (Publishers) Ltd. Environmental Engineering, 116 (5): 805-828.

Dahiya, N.; R. Tewari; R.P. Tiwari and G.S. Hoondal .2005. Chitinase from Enterobacter sp. NRG4: Its purification, characterization and reaction pattern. Electronic J. Biotechnol, 8: 134-145.

Driss, F.; S. Rouis; H. Azzouz; S. Tounsi; N. Zouari and S. Jaoua .2011. Integration of a recombinant chitinase into Bacillus thuringiensis parasporal insecticidal crystal. Curr Microbiol, 62: 281-288.

Dulmage, H.T. and E. Martinez . 1973. The effects of continuous exposure to low concentrations of the dendotoxin of Bacillus thuringiensis on the development of the tobacco budworm, Heliothis virescens. J. Invertebr. Pathol, 22: 14-22.

Dutton, A.; H . Klein; J . Romeis and F. Bigler. 2003. Preymediated effects of Bacillus thuringiensis spray on the predator Chrysoperla carnea in maize. Biological Control, 26: 209-215.

El- Adl, A. M.; K. A. Zaied; Kawther S. Kash; A. I. El Sayed and Mervat I. kamal .2016. Chitinolytic Activity and Feeding Deterrence Efects of New Reccombinants From Bacillus thuringiensis Against Larvae of Spodoptera Littoralis . African Journal of Microbiology Research ( Accepted ).

Ellar,D. J. and J. A. Posgate.1974. In Spore Research 1973 (Barker, A. N., Gould,G. W. \& Wolf, J., eds.), pp. 21-40, Academic Press, London.
Fan, Y.; W.Fang; S.Guo; X. Pei; Y. Zhang; Y. Xiao; D. Li; K. Jin; Michae J. Bidochka and Y. Pei1. 2007. Increased Insect Virulence in Beauveria bassiana Strains Overexpressing an Engineered Chitinase.Applied and Environmental Microbiology, 73(1) : 295-302.

Farrand, S. K .1993. Conjugal transfer of Agrobacterium plasmids. Pp. 255-291 in D. B. Clewell, ed. Bacterial conjugation. Plenum Press, New York.

Finney, D.J .1971. Probit analysis, $3^{\text {rd }}$ edn. Cambridge University Press, U.K.

Giustolin, T. A.; J. D. Vendramim; S. B. Alves; S. A. Vieira and R. M. Pereira.2001. Susceptibility of Tuta absoluta (Meyrick) (Lep., Gelechiidae) reared on two species of Lycopersicon to Bacillus thuringiensis var. kurstaki. J. Appl. Ent, 125: 551556.

Gobbi, A.; F. Budia; M. Schneider; P. Del Estal; S. Pineda and E. Vinuela.2000. Accion del tebufenocida sobre Spodoptera littoralis (Boisduval), Mythimna unipuncta (Haworth) ySpodoptera exigua (Hübner). Bol. San. Veg. Plagas, 26: 119127.

Gonza' 'ez-Cabrera, J.; O. Molla; H. Monton; A. Urbaneja .2011.Efficacy of Bacillus thuringiensis (Berliner) in controlling the tomato borer, Tuta absoluta (Meyrick) (Lepidoptera: Gelechiidae) . Bio Control, 56:71-80.

Gordon, S. A. B.; Stewart; K. Johnstone; E. Hagelberg and D. J. Ellar.1981. Commitment of bacterial spores to germinate $\mathrm{A}$ measure of the trigger reaction. Iochem. J. 198: 101-106.

Grinsted, J.; P. M. Bennett. 1990. Methods in Microbiology: Plasmid Technology (second edition) Published by Academic Press ISBN 10: 0123039703 ISBN 13: 9780123039705.

Grohmann, E. ; G. Muth and M. Espinosa.2003. Conjugative Plasmid Transfer in Gram-Positive Bacteria. Microbiology and Molecular Biology Reviews p. 277-301.

Habib, M. E. M. and M. E. C. Amaral.1985. Aerial application of Bacillus thuringiensis against the velvetbean caterpillar Anticarsia gemmatalis Huebner, in soybean fields. Revista de Agricultura, 60(2): 141-149.

Hafsi, A.; K. Abbes; B. Chermiti and B. Nasraoui, 2012. Response of the tomato miner Tuta absoluta (Lepidoptera: Gelechiidae) to thirteen insecticides in semi-natural conditions in Tunisia. OEPP/EPPO Bulletin, 42(2): 312- 316.

Harris, A. K. P.; N. R. Williamson; H. Slater; A . Cox; S.Abbasi; I. Foulds; H.T. Simonsen; F. J. Leeper and G. P. C. Salmond.2004. The Serratia gene cluster encoding biosynthesis of the red antibiotic, prodigiosin, shows species and strain dependent genome context variation. Microbiology, 150: 3547-3560.

Haynes, K. F. 1988. Sublethal effects of neurotoxic insecticides on insect behavior. Annu. Rev. Entomol. 33: 149 - 168. 
Hellmich, R. L.; B. Siegfried; M. K. Sears; D. E. StanleyHorn; M. J. Daniels; H. R. Mattila; T. Spencer; K. G. Bidne and L. Lewis .2001. Monarch larvae sensitivity to Bacillus thuringiensis purified proteins and pollen. Proceedings of the National Academy of Sciences of the USA , 98: 1192511930.

Hernandez - Fernandez, J. L.; N. Ramirez; L. S. Fuentes and J. Jimenez. 2010. Molecularand biological characterization of native Bacillus thuringiensis strain for controlling tomato leafminer (Tuta absoluta Meyrik) (Lepidoptera: Gelechiidae) in Colombia. World Jornal of Microbiology and Biotechnology, pp. 579- 59.

IAN: Instituto Agron mico Nacional and Agencia de Coperacin Internacional de japn (JICA) 1994. Control integradode la palomilla del tomate Scrobipalpula absoluta (Meyrick, 1917). Caacupé, Paraguay, JICA. p. 173.

Isman M.B.; O. Koul; A. Luczyński and A. Kamiński .1990. Insecticidal and antifeedant bioactivity of neem oils and their relationship to azadirachtin content. Journal of Agricultural and Food Chemistry, 38 (6): 1406-1411.

Jamoussi, K.; S. Sellami; Zina Nasfi; S. Krichen-Makni and S. Tounsi.2013. Efficiency and Midgut Histopathological Effect of the Newly Isolated Bacillus thuringiensis $\mathrm{KS} \delta$-Endotoxins on the Emergent Pest Tuta absoluta. J. Microbiol. Biotechnol, 23(8), 1099-1106.

Johnson, D. E. and B. Freedman .1981. Toxicity of Bacillus thuringiensis Spo- Cr+ Mutants for the European Corn Borer Ostrinia nubilalis. Applied and Environmental Microbiology, Aug. 1981, p. 385-387.

Jyoti, J.L.; S.Y. Young; D.T. Johnson and R.W. McNew. 1996. Helicoverpa zea (Lepidoptera: Noctuidae): larval location, mortality, and leaf area consumption on Bacillus thuringiensis-treated cotton. Environ. Entomol, 25, 1438-1443.

Kamil, Z.; M. Rizk; M. S. Saleh and Moustafa.2007. Isolation and identification of rhizosphere soil chitinolytic bacteria and their potential in antifungal biocontrol. Global Journal of Molecular Sciences, 2 (2): 57-66.

Karamanlidou, G.; A. F. Lambropoulos; S. I. Koliais; T. Manousis and D. Ellar.1991. Toxicity of Bacillus thuringensis to laboratory populations of the olive fruit fly (Dacus oleae). Appl Environ Microbiol, 57: 2277-2282.

Kuzu, S. B.; H. K. Guvenmez and A. A. Denizci .2012. Production of a Thermostable and Alkaline Chitinase by Bacillus thuringiensis subsp. kurstaki Strain HBK-51. Biotechnology Research International . Article ID 135498, 6 pages .

Marques, I.M.R and S.B .Alves .1996. Efeito de Bacillus thuringenesis Berl. Var. Kurstaki sobra Scrobipalpuloides absoluta Meyer .( Lepidoptera: Gelechiidae). An. Soc. Entomol. Brasil, 25: 39-45.

Mathivanan, N.; V. Kabilan and K. Murugesan .1997. Production of chitinase by Fusarium chlamydosporum, a mycoparasite to groundnut rust, Puccinia arachidis. Indian J. Exp. Biol, 35: 890893.
Mazodier, P. and J. Davies. 1991. Gene transfer between distantly related bacteria. Annu. Rev. Genet,25:147-171.

Meissle, M.; C. Pilz and J. Romeis.2009. Susceptibility of Diabrotica virgifera virgifera (Coleoptera: Chrysomelidae) to the Entomopathogenic Fungus Metarhizium anisopliae when Feeding on Bacillus thuringiensis Cry3Bb1-Expressing Maize. Applied and Environmental Microbiology, p. 3937-3943.

Miyasono, M.; S. Inagaki; M. Yamamoto; K. Ohba; T. Ishiguro; R. Takeda and Y. Hayashi. 1994. Enhancement of d-endotoxin activity by toxin-free spore of Bacillus thuringiensis against the diamondback moth, Plutella xylostella. J. Invertebr. Pathol, 63:111-112.

Ozgen, A.; K. Sezen; I. Demir; Z. Demirbag and R. Nalcacioglu .2013. Molecular characterization of chitinase genes from a local isolate of Serratia marcescens and their contribution to the insecticidal activity of Bacillus thuringiensis strains. Curr Microbiol, 67: 499-504.

Pineda, S.; M.I. Schnelder; E. Smagghe; A.M. Martinez; P.D. Estal; E.Vinuela; J.Valle and F.Budla.2007. Lethal and sublethal effects of methoxyfenozide and spinosad on $S$. littoralis (Lepidoptera: Noctuidae). J. Econ, Entomol, 100 (3): 773-780.

Prasifka, P. L.; R. L. Hellmich ; J. R. Prasifka and L. C. Lewis.2007. Effects of Cry1Ab-Expressing Corn Anthers on the Movement of Monarch Butterfly Larvae. Environ. Entomol, 36(1): 228-233.

Reid, J. D. and D.M. Ogrydziak .1981. ChitinaseOverproducing Mutant of Serratia marcescens . Applied and Environmental Microbiology , p. 664669.

Rey, M.W.; P. Ramaiya; B. A. Nelson; S. D. BrodyKarpin; E. J. Zaretsky; M. Tang; A.Lopez de Leon; H. Xiang; V.Gusti ; I. G . Clause ; P. B. Olsen; M. D. Rasmussen; J. T.Andersen; P. L.Jorgensen; T.S. Larsen; A. Sorokin; A.Bolotin; A. Lapidus; N.Galleron; S.D.Ehrlich and R.M. Berka. 2004. Complete genome sequence of the industrial bacterium Bacillus licheniformis and comparisons with closely related Bacillus species. Genome Biology, 5(10): R77.1: R77.12.

Roh, J. Y.; Y. C. Jae; S. L. Ming; R. J. Byung and H. E. Yeon. 2007. Bacillus thuringiensis as a specific, safe, and effective tool for insect pest control. J. Microbiol. Biotechnol, 17(4): 547-559.

Romeis, J.; M. Meissle; A. Raybould and R.L. Hellmich. 2009. Impact of insect-resistant genetically modified crops on above-ground non-target arthropods, p. 165-198. In N. Ferry and A. M. R. Gatehouse (ed.), Environmental impact of genetically modified crops. CABI Publishing, Wallingford, United Kingdom.

Sabbour M. M. 2014. Biocontrol of the Tomato Pinworm Tuta absoluta (Meyrick) (Lepidoptera: Gelechiidae) in Egypt. Middle East Journal of Agriculture Research, 3(3): 499-503.

Sambrook, J.; E. L. Fritschand and T. Maniatis .1989 .Molecular cloning. A laboratory manual, $2^{\text {nd }}$ edn. Cold Spring Harbor Laboratory, Cold Spring Harbor, NY . 
Sampson, M.N and G.W. Gooday .1998. Involvement of chitinase of Bacillus thuringiensis during pathogenesis in insects. Microbiology144:21892194.

Schnepf, E.; N. Crickmore; J. Van Rie; D. Lereclus; J. Baum; J. Feitelson; D.R. Zeigler and D.H. Dean. 1998. Bacillus thuringiensis and its pesticidal crystal proteins. Microbiol. Mol. Biol. Rev. 62, 775-806.

Singh, H.; K. K. Shukla and A. K. Dhawan.2008. Effects of Bacillus thuringiensis $\delta$-endotoxin on life history parameters of rice leaf folder Cnaphalocrocis Medinalis (Lepidoptera) .Indian J. Agric. Res., 42 (3) : 183 -188.

Singh,G.; P.J. Rup and O.Koul .2007. Acute, sublethal and combination effects of azadirachtin and Bacillus thuringiensis toxins on Helicoverpa armigera (Lepidoptera: Noctuidae) larvae. Bull Entomol Res., 97:351-357.

Smagghe, G.; E.Vinuela; F. Budia and D. Degheele.1997. Effects of the non-steroidal ecdysteroid mimic tebufenozide on tomato looper Chrysodeixis chalcites (Lepidoptera: Noctuidae). An ultrastructural analysis Arch. Insect. Biochem. Physiol, 35: 179-190.

Snedecor, G. W. and W. G. Cochran.1955. Statistical Methods, sixth edition. The Iowa state University Press, Ames, Iowa, U.S.A.

Someya N. Ikeda.; S. Morohoshi;T. Morohoshi; M.N. Tsujimoto; T. Yoshida; H. Sawada;T. Ikeda and K. Tsuchiya.2011. Diversityof culturable chitinolytic bacteria from rhizospheres of agronomic plants in Japan. Microbes and Environments, 26( 1): 7- 14.

Stanley-Horn, D. E.; G. P. Dively; R. L. Hellmich; H. R. Mattila; M. K. Sears; R. Rose; L. C. H. Jesse; J. E. Loseyi; J. J. Obrycki and L. Lewis.2001 . Assessing the impact of Cry1Ab-expressing corn pollen on monarch butterfly larvae in field studies. PNAS u , 98. (21 ) : 11931-11936.

Sun, Y.P. 1950. Toxicity index - An Improved method of comparing the relative toxicity of insecticides. J. Econ. Entomol., 43 (1): 45-53.
Suzuki, K.; Sugawara; M. Suzuki; T. Uchiyama; F. Katouno; N. Nikaidou and T.Watanabe .2002. Chitinases A, B, and C1 of Serratia marcescens 2170 produced by recombinant Escherichia coli: enzymatic properties and synergism on chitin degradation. Biosci Biotechnol Biochem, 66: 10751083.

Tabashnik, B. E.; N. Finson and M. W. Johnson. 1991. Managing resistance to Bacillus thuringiensis: lessons from the diamondback moth (Lepidoptera: Plutellidae). Journal of Economic Entomology, 84: 49-55.

Terra, W.R and C. Ferreira. 2005. Biochemistry of digestion, in: L.I. Gilbert, K. Iatrou, S.S. Gill (Eds.).Comprehensive Molecular Insect Science Biochem. and Mol. Biology, Elsevier Press, Oxford, $U K$, pp. 171-224.

Thamthiankul, S.; S. Suan-Ngay; S. Tantimavanich and W. Panbangred. 2001. Chitinase from Bacillus thuringiensis subsp. Pakistani. Appl Microbiol Biotechnol 56:395-401.

Wiwat, C.; S. Thaithanun; S. Pantuwatana and A. Bhumiratana . 2000. Toxicity of chitinaseproducing Bacillus thuringiensis ssp. kurstaki HD-1 (G) toward Plutella xylostella. J. Invertebr Pathol., 76(4):270-277.

Yee, W. L. and N. C.Toscano. 1998. Laboratory evaluations of synthetic and natural insecticides on beet armyworm (Lepidoptera: Noctuidae) damage and survival on lettuce. J. Econ. Entomol. 91: 56 63.

Youssef, N. A. and Hassan, G. M. 2013. Bioinsecticide activity of Bacillus thuringiensis isolates on tomato borer, Tuta absoluta (Meyrick) and their molecular identification" African Journal of Biotechnology, 12(23): 3699-3709.

Yu, H.; Y. Li; X. Li; J. Romeis and K. Wu. 2013. Expression of Cry1Ac in transgenic Bt soybean lines and their efficiency in controlling lepidopteran pests. Pest Manag. Sci, 69:1326-1333.

Zhao, B.; G. G. Grant; D. Langevin and L. MacDonald. 1999. Deterring and inhibiting effects of quinolizidine alkaloids on spruce budworm (Lepidoptera: Tortricidae) oviposition. Environ. Entomol, 27: 984-992.

\section{التأثير المضيف لجينات الثيتينيز في المتحولات التزاوجية للباسيلس ثيرونجنسز لتحسين المكافحة الحيوية لحشرة التوتا أبسلوتا

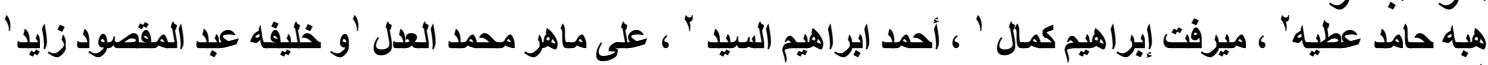

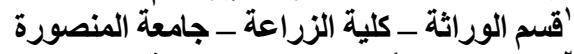

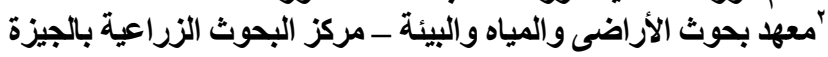

تم إجر اء هذه الدر اسة بغرض تقييم سمية المتحو لات التزاوجية من الباسيلس ثيرونجنسز التى تحمل المزيد من الجينات المنتجة لإنزيم

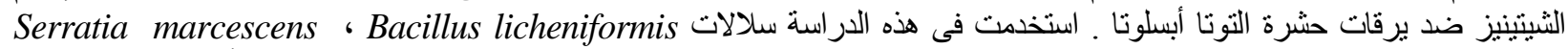

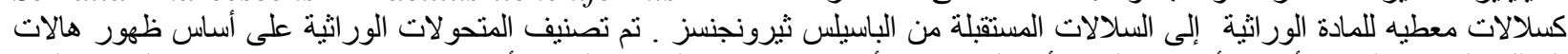

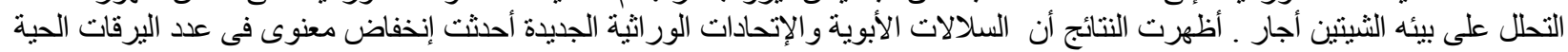

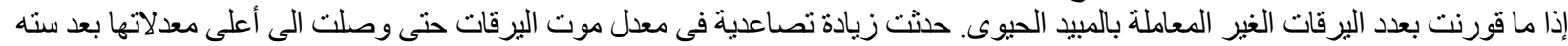

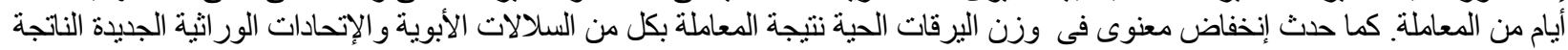

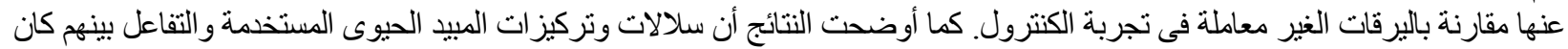

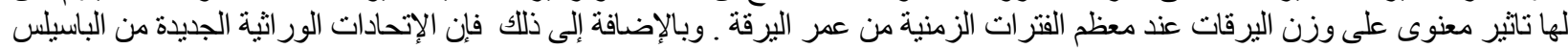
ثيرونجنسز وكذلك السلالات الأبوية كان لها تأثثير كبير فى مقاومة الحشرة المستهدفة وتوقف الطور اليرقى عن التغذية على عو ائلة النباتية . 